\section{Triple oxygen isotopes of meteoric hydrothermal systems - implications for palaeoaltimetry}

\section{C.P. Chamberlain ${ }^{1 *+}$, D.E. Ibarra ${ }^{1,2+}$, M.K. Lloyd ${ }^{2}$, T. Kukla1, D. Sjostrom ${ }^{3}$, Y. Gao ${ }^{1,4}$, Z.D. Sharp ${ }^{5}$}

Abstract

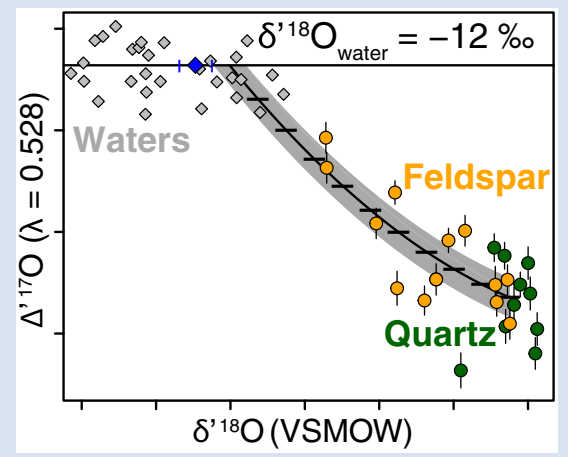

We use triple oxygen isotopes of altered granitic rocks to determine the isotope composition of meteoric waters in a fossil hydrothermal system, the low $\delta^{18} \mathrm{O}$ Eocene Idaho Batholith, originally studied by Criss and Taylor (1983). In doing so we: 1) test whether meteoric water values estimated from previous $\delta^{18} \mathrm{O}$ and $\delta \mathrm{D}$ analyses on quartz, feldspar and biotite are robust and 2) determine the palaeoelevation of the Eocene highlands that are presently constrained primarily by the $\delta^{18} \mathrm{O}$ and $\delta \mathrm{D}$ of paired muscovite and quartz from core complexes and altered granites.

Our calculated $\delta^{18} \mathrm{O}$ values of meteoric water are higher than estimates that use combined feldspar $\delta^{18} \mathrm{O}$ and biotite $\delta \mathrm{D}$ measurements in these hydrothermally altered granites and $\delta \mathrm{D}$ values from muscovite from nearby core complexes (Mulch et al., 2004). Both methods are consistent with a high elevation ( 3.1 to $4.7 \mathrm{~km})$ Eocene highland in the northwestern U.S. Cordillera.

Received 7 March 2020 | Accepted 26 May 2020 | Published 28 July 2020

\section{Introduction}

With the advent of stable isotope palaeoaltimetry it has been possible to determine the past elevations of the worlds major mountain belts by exploiting the relationship between $\delta^{18} \mathrm{O}$ and $\delta \mathrm{D}$ of meteoric waters and elevation as described by Rayleigh distillation over orography (Poage and Chamberlain, 2001; Rowley et al., 2001). Multiple proxies for the isotopic composition of meteoric waters have been used for these elevation reconstructions. These include the $\delta \mathrm{D}$ of 1 ) organic molecules from fossilised leafs (Hren et al., 2010), hydrated volcanic glasses (Mulch et al., 2008), pedogenic clays (Chamberlain et al., 1999), hydrothermal micas (Mulch et al., 2004), fluid inclusions of quartz veins (Sharp et al., 2005); and the $\delta^{18} \mathrm{O}$ of 2) pedogenic and lacustrine carbonate (Quade et al., 2007), lacustrine chert (Davis et al., 2009), and pedogenic clays (Mix and Chamberlain, 2014). While these proxies are excellent predictors of the isotopic composition of meteoric waters they are limited by their geographic location as many occur only in the sedimentary basins that flank the crystalline cores of mountain belts. Nowhere is this more prevalent than in the North American Cordillera where almost all palaeolevation estimates come from intermontane basins that are adjacent to crystalline uplifts (Chamberlain et al., 2012; Fig. 1).
Most determinations of the isotopic composition of meteoric waters using crystalline rocks rely on the $\delta \mathrm{D}$ of micas from hydrothermally altered rocks within fault zones (Mulch et al., 2004) or altered granites (Criss and Taylor, 1983). A potential problem with this approach is that hydrogen isotopes of phyllosilicates may continue to exchange well after crystallisation. For example, O'Neil and Kharaka (1976) showed that exchange of hydrogen, but not oxygen, occurred in clay minerals at temperatures above $100{ }^{\circ} \mathrm{C}$. It is also possible that micas may be exchanging $\mathrm{H}$ rather than $\mathrm{OH}$ groups and that this exchange occurs at temperatures typical of cooling crystalline rocks. If this is the case, then the oxygen and hydrogen isotope values of micas may be decoupled and cooling rate dependent (Graham et al., 1987). Hence, the motivation of this study is to use triple oxygen isotopes to determine the isotopic composition of meteoric waters. Unlike the $\mathrm{H}-\mathrm{O}$ system, the ${ }^{17} \mathrm{O} /{ }^{16} \mathrm{O}$ and ${ }^{18} \mathrm{O} /{ }^{16} \mathrm{O}$ systems are not decoupled, and should change in concert during alteration.

To estimate the isotopic compositon of meteoric water in a hydrothermal system, we modify the approach of Herwartz et al. (2015) who used arrays of triple oxygen isotopes on a suite of rocks to determine the $\delta^{18} \mathrm{O}$ of alteration waters during a Snowball Earth event (see also Zakharov et al., 2017). Here, we use mixing equations (Taylor, 1978) modified for ${ }^{17} \mathrm{O}$ to

\footnotetext{
Geological Sciences, Stanford University, Stanford, California 94305, USA

Earth and Planetary Science, UC Berkeley, Berkeley, California 94720s, USA

Geology Program, Rocky Mountain College, Billings, Montana 59102, USA

Earth Sciences and Resources, China University of Geosciences (Beijing), Beijing, 100083 China

Earth and Planetary Sciences, University of New Mexico, Albuquerque, New Mexico 87131, USA

Corresponding author (email: chamb@stanford.edu)

C.P. Chamberlain and D.E. Ibarra contributed equally to this work.
} 


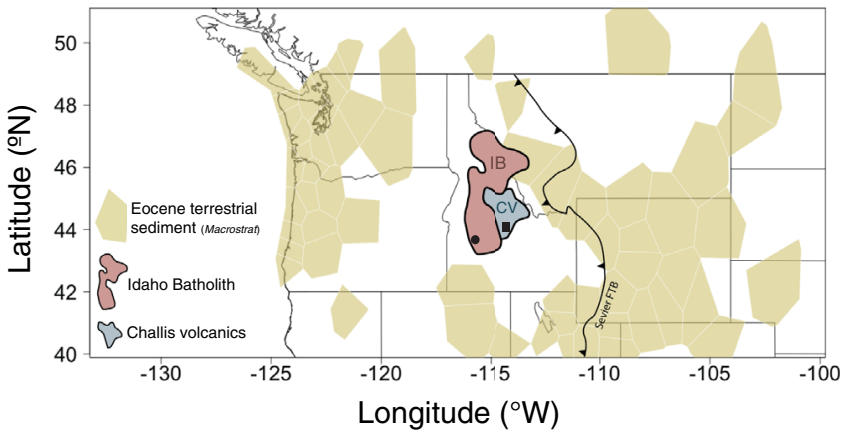

Figure 1 Map of Idaho batholith and surrounding Eocene basins. Symbols represent the study area (dot), and the Pioneer core complex (square).

determine the palaeoelevation of Eocene hydrothermally altered rocks of the Idaho batholith (Criss and Taylor, 1983). We show that triple oxygen isotopes correspond to Eocene meteoric water values that are higher than those determined by hydrogen isotope analysis, suggesting that retrograde hydrogen, but not oxygen, isotope exchange has occurred between micas and fluids.

\section{Geologic Setting}

The Idaho batholith $\left(\sim 25000 \mathrm{~km}^{2}\right)$ lies within the crystalline core of the North American Cordillera. It is flanked on both the west and east by Cenozoic intermontane basins that contain debri eroded from the batholith and surrounding rocks (Fig. 1). The batholith is Cretaceous to Eocene in age and consists of granites and granodiorites (Gaschnig et al., 2010). The batholith was hydrothermally altered during the emplacment of the Eocene plutons and eruption of the Challis volcanics. Using hydrogen and oxygen isotopes of minerals from these Eocene granites, Criss and Taylor (1983) demonstrated that the hydrothermal systems consisted of meteoric waters within flow systems centred on the Eocene plutons. The hydrothermal centre targeted here, the Rocky Bar complex, lies in the southwest corner of the Idaho Batholith.

The Rocky Bar complex was emplaced ( $48 \mathrm{Ma}$; Gaschnig et al., 2010) and hydrothermally altered ( 45 to $37 \mathrm{Ma}$; Criss et al., 1982) during the Eocene. The alteration of the pluton and wallrocks is evidenced by low $\delta^{18} \mathrm{O}$ values of plagioclase (down to $-2.5 \%$ ), with the lowest values occuring near the core of the pluton and along the faults that ring the complex. Guided by the results of Criss and Taylor (1983), we collected granites from the Rocky Bar complex exposed along Highway 21 that transects the complex (Table S-1).

\section{Results}

Our analysis of $\delta^{18} \mathrm{O}, \delta^{17} \mathrm{O}$ of plagioclase and quartz, and $\delta \mathrm{D}$ of biotite give three results, which are:

First, the $\delta^{18} \mathrm{O}$ of plagioclase has larger variations than that of quartz. The $\delta^{18} \mathrm{O}$ of plagioclase ranges from -3.6 to $8.8 \%$; quartz $\delta^{18} \mathrm{O}$ values range from 5.5 to $10.7 \%$ (Table S-1). Moreover, the $\delta^{18} \mathrm{O}$ of coexisiting mineral pairs form disequilibrium arrays (Fig. 2) similar to those discovered by Criss and Taylor (1983). Second, the $\Delta^{\prime 17} \mathrm{O}\left(\delta^{\prime 17} \mathrm{O}-0.528 \times \delta^{\prime 18} \mathrm{O}\right)$ of plagioclase, like the $\delta^{18} \mathrm{O}$ values, show a wider range than that of quartz. $\Delta^{17} \mathrm{O}$ of plagioclase ranges from -0.004 to -0.095 , and $\Delta^{117} \mathrm{O}$ of quartz ranges from -0.058 to -0.118 . Third, the $\delta^{18} \mathrm{O}$ of feldspar and $\delta \mathrm{D}$ values of biotite also form a water-rock mixing array (Fig. 4, Table S-1).

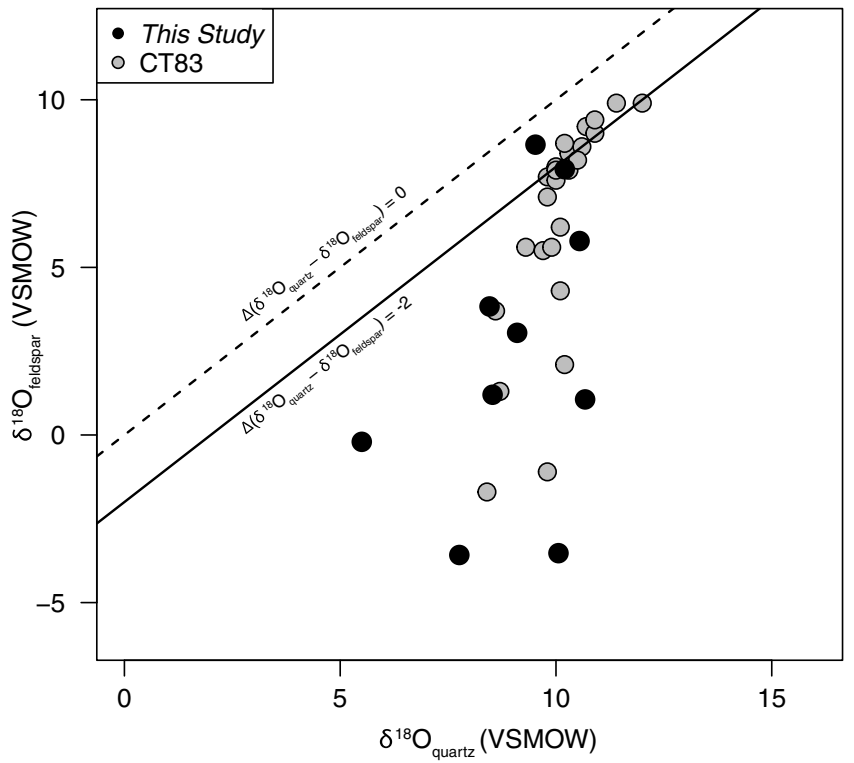

Figure $2 \delta^{18} \mathrm{O}_{\text {quartz }}$ versus $\delta^{18} \mathrm{O}_{\text {plagioclase }}$ for coexisiting mineral pairs. Black dots are this study and gray dots those of Criss and Taylor (1983). Shown are the $\Delta_{\text {qtz-plag }}$ for 0 and $2.0 \%$. $2.0 \%$ is the equilibrium fractionation between quartz and feldpsar for granitic rocks (O'Neil and Taylor, 1967).

\section{Interpretation}

Our results agree with the interpretation that the oxygen and hydrogen isotopes reflect a high temperature hydrothermal system during emplacment of the Eocene plutons (Criss and Taylor, 1983). Disequilibrium arrays of the oxygen isotopes of paired quartz and plagioclase (Fig. 2) result from differential exchange between fluids and quartz/feldspar during hydrothermal activity, with feldspar exchanging more rapidly than quartz. These kinetic controls are also reflected in the $\Delta^{\prime 17} \mathrm{O}$ values.

The kinetic effects are evidenced by the wide range of $\lambda_{\text {quartz-feldspar }}$ values. Note that, following Pack and Herwartz (2014) and Sharp et al. (2018), we use $\theta$ to represent the theoretical slope, whereas $\lambda$ is used to represent the empirical slope using data. As stated above our $\lambda_{\text {quartz-feldspar values range from }}$ 0.5152 to 0.5305 (Table S-1). The theoretical high temperature slope is $\theta=0.5305$ (Young et al., 2002). Given the wide range of $\lambda_{\text {quartz-feldspar }}$ values (Table S-1) and the narrow temperature range experienced by these granites and high temperature fluids it is highly unlikely that these minerals are in isotopic equilibrium. Thus, our results are consistent with the interpretation of Criss and Taylor (1983), but with the added constraint that we can calculate the meteoric water composition using oxygen isotopes alone.

To determine the oxygen isotopic composition of meteoric water we used the array of $\delta^{\prime 18} \mathrm{O}$ and $\Delta^{\prime 17} \mathrm{O}$ (Fig. 3) values for plagioclase. A fit through this array (see Supplementary Information) using the water-rock equations of Taylor (1978) assuming a $400{ }^{\circ} \mathrm{C}$ alteration temperature, gives a value of $\delta^{18} \mathrm{O}$ of meteoric water of $-11.99 \%( \pm 1.11,1 \sigma)$. Propagating the unceratiny around the meteoric water line of Passey and Ji (2019) (dashed lines in Fig. 3) and the best fit regression shown in Figure 3, produces a field spanning -10 to $-15 \%$ (see Table S-2). Additionally, if the feldspar- $\mathrm{H}_{2} \mathrm{O}$ interaction is set to a colder temperature, such as $250^{\circ} \mathrm{C}$, rather than the maximum $400{ }^{\circ} \mathrm{C}$ assumed by Criss and Taylor (1983), we calculate a $\delta^{18} \mathrm{O}$ of meteoric water of $-15 \%$ (Fig. S-1). However, this lower temperature is probably unreasonable given that it is below the closure temperature of the dated hydrothermal micas 
(Criss and Taylor, 1983). Regardless, it is clear that the Eocene meteoric water has a low $\delta^{18} \mathrm{O}$ value. However, our $\delta^{18} \mathrm{O}$ value is higher than that determined previously (approximately $-16 \%$ ) by Criss and Taylor (1983) who use both $\delta^{18} \mathrm{O}$ and $\delta \mathrm{D}$ values. Our $\delta^{18} \mathrm{O}-\delta \mathrm{D}$ data give results similar to Criss and Taylor (1983) with a best fit to the data of $\delta^{18} \mathrm{O}=-15.25 \%$ $( \pm 1.12,1 \sigma$; Fig. 4$)$.

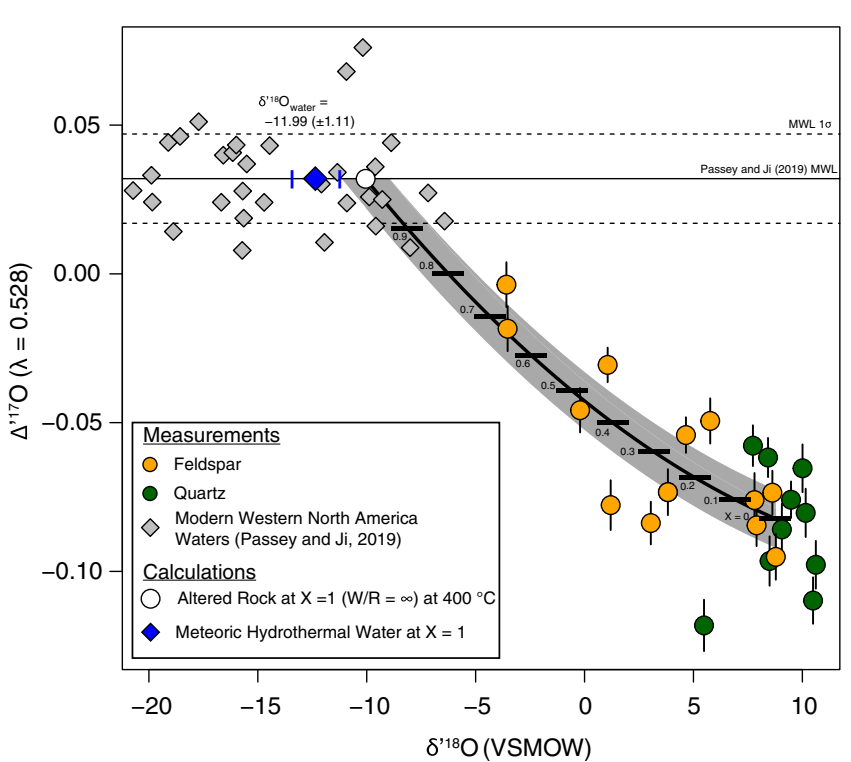

Figure 3 The $\delta^{\prime 18} \mathrm{O}-\Delta^{\prime 17} \mathrm{O}$ alteration relationship of feldspar used to derive meteoric water. Meteoric water lines and compiled modern water data are from Passey and Ji (2019). Given are the 1 s.e. bars for the measurements. The black line is the alteration array between unaltered rock and rock in equilibrium with the metoric water fit to the feldspar data for fractional mixing (Taylor, 1978).

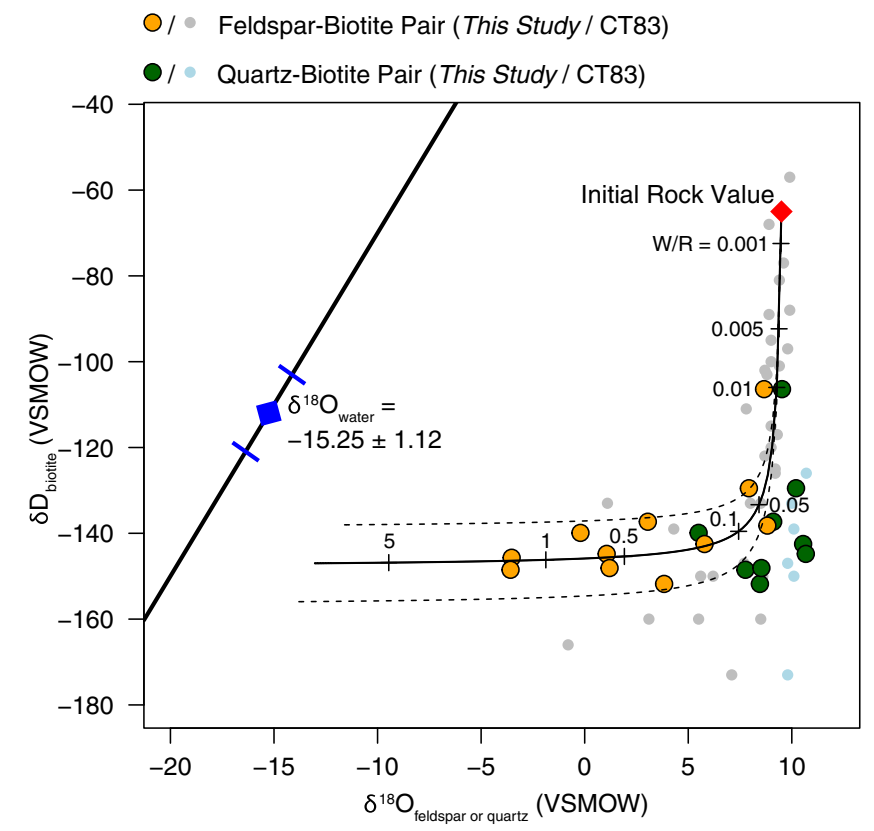

Figure 4 The $\delta^{18} \mathrm{O}-\delta \mathrm{D}$ array for feldspar-biotite (this study; Criss and Taylor, 1983) with water/rock (W/R) values of the molar fraction of oxygen given the best fit meteoric water value. W/R values assume fractionation factors of feldspar- $\mathrm{H}_{2} \mathrm{O}=+2 \%$ for $\delta^{18} \mathrm{O}$ and biotite- $\mathrm{H}_{2} \mathrm{O}=-35 \%$ for $\delta \mathrm{D}$ (Taylor, 1977). Quartz values were not used for calculations.

\section{Discussion and Conclusions}

Most estimates of the isotopic composition of meteoric waters that interacted with crystalline rocks rely on the hydrogen isotope composition of the altered rocks. The isotopic composition of these waters is either calculated directly from $\delta \mathrm{D}$ values of hydrous minerals and using temperatures from oxygen isotope thermometry (Mulch et al., 2004) or from combined oxygen and hydrogen isotope analyses of rocks and their hydrothermally altered end members and the mixing relationships between them (Criss and Taylor, 1983). Because of the possibility of exchange of hydrogen between minerals and later fluids it is a concern that estimates of the original composition of the meteoric water in these hydrothermal systems is compromised. This difference in calculated meteoric water compositons is measurable and can lead to error in estimates of the isotopic composition of meteoric waters during hydrothermal activity. The error then translates directly to error in palaeoelevation estimates, particularly at low elevations.

For example, we demonstrate that based on the extrapolated mixing relationships in triple oxygen isotope space using feldspar analyses give calculated meteoric water values, assuming $400{ }^{\circ} \mathrm{C}$, that are $\sim 2.7$ to $3.9 \%$ o (Table S-2) higher than those determined using combined oxygen and hydrogen isotopes. We note that this difference in calculated meteoric water values is dependent upon the assumed temperature of the hydrothermal system and the choice of the meteoric water lines in $\delta^{\prime 18} \mathrm{O}$ and $\Delta^{\prime 17} \mathrm{O}$ space (Table S-1). If we take the maximum temperature of the hydrothermal system of $400{ }^{\circ} \mathrm{C}$ (Criss and Taylor, 1983) will this isotopic difference translate into an elevation difference that is significant? To test this we use the data presented here, with that published on nearby Eocene ( 38 to $37 \mathrm{Ma}$ ) Pioneer core complexes (McFadden et al., 2015) and the Idaho batholith (Criss and Taylor, 1983) (Fig. 1). These three studies all differ in their calculation of the isotopic composition of meteoric waters. Ours is based on triple oxygen and the others rely on hydrogen isotopes. McFadden et al. (2015) use the $\delta D$ values of micas from detachment faults active in the late Eocene and assumed temperature of formation of these detachments and calculate a $\delta^{18} \mathrm{O}$ of meteoric water of $-16.0 \pm 1.5 \%$. Criss and Taylor (1983) use $\delta \mathrm{D}$ of biotites and muscovite and the $\delta^{18} \mathrm{O}$ of feldspar and vein quartz and arrive at the same $\delta^{18} \mathrm{O}$ of meteoric water of $-16 \%$ o. Using the equations for Eocene lapse rates of Rowley et al. (2001), the Eocene elevation of the Idaho batholith was $4.74 \mathrm{~km}(+0.64 /-0.49,1 \sigma$ of the Rowley model) based on hydrogen isotopes. Using the best fit of meteoric water at $400{ }^{\circ} \mathrm{C}$ alteration temperature $(-11.92 \%$ ) we estimate a lower Eocene elevation of $3.11 \mathrm{~km}+0.31 /-0.38(1 \sigma)$, based on triple oxygen isotopes. At $1 \sigma$ and even at $2 \sigma$ these values do not overlap, though they do overlap at $2 \sigma$ using other meteoric water lines (Table S-2). Nonetheless, we suggest that later hydrogen exchange, at least in this case, results in inaccurate palaeoelevation estimates.

\section{Acknowledgements}

This research was funded by NSF EAR-1322084 and Heising Simons grants to CPC. DEI was supported by Miller Research Institute and UC President's Postdoctoral Fellowships. MKL was supported by the Agouron Institute Geobiology Fellowship. We thank Daniel Herwartz and Andreas Pack for reviews.

Editor: Eric H. Oelkers 


\section{Additional Information}

Supplementary Information accompanies this letter at http:// www.geochemicalperspectivesletters.org/article2026.

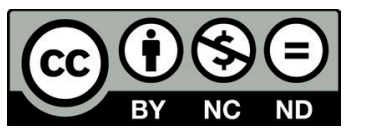

(C) 2020 The Authors. This work is distributed under the Creative Commons Attribution NonCommercial No-Derivatives 4.0 License, which permits unrestricted distribution provided the original author and source are credited. The material may not be adapted (remixed, transformed or built upon) or used for commercial purposes without written permission from the author. Additional information is available at http://www. geochemicalperspectivesletters.org/copyright-and-permissions.

Cite this letter as: Chamberlain, C.P., Ibarra, D.E., Lloyd, M.K., Kukla, T., Sjostrom, D., Gao, Y., Sharp, Z.D. (2020) Triple oxygen isotopes of meteoric hydrothermal systems - implications for palaeoaltimetry. Geochem. Persp. Let. 15, 6-9.

\section{References}

Chamberlain, C.P., Poage, M., Craw, D., Reynolds, R. (1999) Topographic development of the Southern Alps recorded by the isotopic composition of authigenic clay minerals, South Island, New Zealand. Chemical Geology 155, 279-294

Chamberlain, C.P., Mix, H.T., Mulch, A., Hren, M.T., Kent-Corson, M.L., Davis, S.J., Horton, T.W., Graham, S.A. (2012) The Cenozoic climatic and topographic evolution of the western North American Cordillera. American Journal of Science 312, 213-262.

CRISS, R.R., TAYLOR, H.P. JR. (1983) An ${ }^{18} \mathrm{O} /{ }^{16} \mathrm{O}$ and D/H study of Tertiary hydrothermal system in the southern half of the Idaho batholith. Geological Society of America Bulletin 94, 640-663.

Criss, R.E., Lanphere, M.A., TAYlor, H.P. JR. (1982) Effects of regional uplift, deformation and meteoric-hydrothermal metamorphism on K-Ar ages of biotites in the southern half of the Idaho Batholith. Journal of Geophysical Research 87, 7026-7046.

Davis, S.J., Mulch, A., Caroll, A.R., Horton, T.W., Chamberlain, C.P. (2009) Paleogene landscape evolution of the central North American Cordillera: Developing topography and hydrology in the Laramide foreland. Geological Society of America Bulletin 121, 100-116.

GaschniG, R.M., Vervoort, J.D., LeWIS, R.S., McClelland, W.C. (2010) Migrating magmatism in the northern US Cordillera: in situ U-Pb geochronology of the Idaho batholith. Contributions to Mineralogy and Petrology 159, 863-883.

GraHam, C.M., Viglino, J.A., Harmon, R.S. (1987) Experimental study of hydrogenisotope exchange between aluminous chlorite and water and of hydrogen diffusion in chlorite. American Mineralogist 72, 566-579.

Herwartz, D., Pack, A., Krylov, D., Xiao, Y., Muehlenbachs, K., Sengupta, S, Di Rocco, T. (2015) Revealing the climate of snowball Earth from $\Delta^{17} \mathrm{O}$ systematics of hydrothermal rocks. Proceedings of the National Academy of Sciences 112, 5337-5341.

Hren, M.T., PAGANI, M., ERWIN, D.M., BRANDON, M. (2010) Biomarker reconstruction of the early Eocene paleotopography and paleoclimate of the northern Sierra Nevada. Geology 38, 7-10.

McFadden, R.R., Mulch, A., Teyssier, C., Heizker, M. (2015) Extension and meteoric fluid flow in the Wildhorse detachment, Pioneer metamorphic core complex, Idaho. Lithosphere 7, 355-366.

Mix, H.T., ChamberLain, C.P. (2014) Stable isotopic records of hydrologic change and paleotemperature from smectite in Cenozoic Western North America. Geochimica et Cosmochimica Acta 141, 532-546.

Mulch, A., Teyssier, C., Cosca, M.A., Vanderhaeghe, O., Vennemann, T. (2004) Reconstructing paleoelevation in eroded orogens. Geology 32, 525-528.

Mulch, A., Sarna-Wojcicki, A.M., Perkins, M.E., Chamberlain, C.P. (2008) A Miocene to Pleistocene climate and elevation record of the Sierra Nevada (California). Proceedings of the National Academy of Sciences of the United States of America 105, 6819-6824.

O'NeIL, J.R., Taylor, H.P. JR. (1967) The oxygen isotope and cation exchange chemistry of feldspars. American Mineralogist 52, 1414-1437.
O'Neil, J.R., KHARAKA, Y.K. (1976) Hydrogen and oxygen isotope exchange reactions between clay minerals and water. Geochimica et Cosmochimica Acta 40, 241-246.

PACK, A., HeRWARTZ, D. (2014). The triple oxygen isotope composition of the Earth mantle and understanding $\Delta \mathrm{O}^{17}$ variations in terrestrial rocks and minerals. Earth and Planetary Science Letters 390, 138-145.

PAssey, B. H., JI, H. (2019) Triple oxygen isotope signatures of evaporation in lake waters and carbonates: A case study from the western United States. Earth and Planetary Science Letters 518, 1-12.

Poage, M.A., Chamberlain, C.P. (2001) Empirical relationships between elevation and the stable isotope composition of precipitation and surface waters: Considerations for studies of paleoelevation change. American Journal of Science 301, 1-15.

Quade, J., Garzione, C., EIler, J. (2007) Paleoelevation reconstruction using pedogenic carbonates. In: KoHN, M. (Ed.) Reviews in Mineralogy and Geochemistry 66, 53-87.

Rowley, D.B., PierrehumberT, R.T., Currie, B.S. (2001) A new approach to stable isotope-based paleoaltimetry: implications for paleoaltimetry and paleohypsometry of the High Himalaya since the Late Miocene. Earth and Planetary Science Letters 188, 253-268.

Sharp, Z.D., Masson, H., LucchinI, R. (2005) Stable isotope geochemistry and formation mechanisms of quartz veins: extreme paleoaltitudes of the central Alps in the Neogene. American Journal of Science 305, 187-219.

SharP, Z.D., WostBrock, J.A.G., PACK, A. (2018) Mass-dependent triple oxygen isotope variations in terrestrial materials. Geochemical Perspectives Letters 7, 27-31.

TAYLOR, H.P. JR. (1977) Water/rock interactions and the origin of $\mathrm{H}_{2} \mathrm{O}$ in granitic batholiths. Journal Geological Society of London 133, 509-558.

TAYLOR, H.P. JR. (1978) Oxygen and hydrogen isotope systematics of plutonic granitic rocks. Earth and Planetary Science Letters 38, 177-210.

Young, E.D., Galy, A. Nagahara, H. (2002) Kinetic and equilibrium massdependent isotope fractionation laws in nature and their geochemical and cosmochemical significance. Geochimica et Cosmochimica Acta 66, 1095-1104.

Zakharov, D.O, Bindeman, IN S S abunov, A.I Ovtcharova, M. Coble, M.A Serebryakov, N.S., Schaltegger, U. (2017) Dating the Paleoproterozoic snowball Earth glaciations using contemporaneous subglacial hydrothermal systems. Geology 45, 667-670. 